Cahiers $d u$ MONDE RUSSE

\section{Cahiers du monde russe}

Russie - Empire russe - Union soviétique et États indépendants

$60 / 1 \mid 2019$

Relations informelles et pratiques sociales dans I'Empire russe au XVIIle siècle | Transports et voies de communication en Russie au début des Temps modernes

\title{
Novgorodskie dorogi XVI veka kak prostranstvennyi instrument administrirovaniia
}

Les routes de Novgorod au XVI' siècle, outil géographique d'administration Sixteenth-century Novgorodian roads, a geographical administrative tool

Aleksei A. Frolov

\section{(2) OpenEdition}

\section{Édition électronique}

URL : https://journals.openedition.org/monderusse/11089

DOI : 10.4000/monderusse. 11089

ISSN : $1777-5388$

Éditeur

Éditions de l'EHESS

\section{Édition imprimée}

Date de publication : 1 janvier 2019

Pagination : 105-132

ISBN : 978-2-7132-2795-0

ISSN : $1252-6576$

Référence électronique

Aleksei A. Frolov, «Novgorodskie dorogi XVI veka kak prostranstvennyi instrument administrirovaniia», Cahiers du monde russe [Онлайн], 60/1 | 2019, Выложить онлайн 01 janvier 2022, Наводить справки в 06 janvier 2022. URL: http://journals.openedition.org/monderusse/11089 ; DOI: https://doi.org/ 10.4000/monderusse. 11089 


\title{
NOVGORODSKIE DOROGI XVI VEKA KAK PROSTRANSTVENNYI INSTRUMENT ADMINISTRIROVANIIA
}

\author{
[Les routes de Novgorod au XVI ${ }^{\mathrm{e}}$ siècle, \\ outil géographique d'administration]
}

Система путей сообщения - чрезвычайно важный элемент организации культурного пространства, поэтому вопросы мобильности населения и транспортной мобильности привлекают к себе внимание исследователей многих аспектов истории общества различных эпох ${ }^{1}$. В силу состояния источниковой базы наиболее полно эти вопросы освещаются при обращении к сюжетам XIX-XX вв. ${ }^{2}$ По мере погружения в историческую ретроспективу исследователи часто ограничиваются специальными вопросами топографии и хронологии функционирования отдельных элементов дорожной инфраструктуры. Благодатную почву для этого дают, прежде всего, регионы, побывавшие в составе Римской империи, которая оставила после себя гигантскую сеть обустроенных дорог, некоторые из них сохранились по сей день.

Привычным ракурсом историко-географического изучения русских дорог Средневековья и Нового времени является их локализация по данным

1. Исследование подготовлено в рамках проекта «Северная Евразия на карте: от Птолемея до современных ГИС-технологий», грант Российского научного фонда №14-18-02121.

2. E.F. Arnold, Negotiating the Landscape: Environment and Monastic Identity in the Medieval Ardennes, Philadelphia: Univ. of Pennsylvania Press, 2013; Э.Г. Истомина, Водные пути России во второй половине XVIII - начале XIX в., М.: Наука, 1982; Она же, «Пути сообщения и транспорт в России в XVI - начале XX в.» в Историческая география России, IX - начало ХХ века. Территория, население, экономика: очерки. М.: Ин-т рос. истории РАН, 2013, c. 166-229; P. Merriman, R. Jones, T. Cresswell et al., «Mobility: Geographies, Histories, Sociologies», Transfers: Interdisciplinary Journal of Mobility Studies, 3 (1), 2013, p. 147-165; C. Divall, G. Revill, «Cultures of Transport: Representation, Practice and Technology», The Journal of Transport History, 26 (1), 2005, p. 99-111; А. Бекасова, «Дилижансы на дорогах России XIX в.: от замысла - к практике воплощения», Quaestio Rossica, т. 5, 2017, № 1, c. $32-55$ 
исторических источников, выяснение вопросов их функционирования, организации ямской гоньбы и обслуживания системы транспортных коммуникаций ${ }^{3}$ Учет маршрутов прохождения дорог часто оказывается необходим для понимания логики развития тех или иных событий и процессов. Однако следует стремиться к тому, чтобы на базе результатов, полученных с помощью специальных историко-географических штудий, получить новое знание, характеризующее особенности общественной жизни соответствующей эпохи - если такие возможности предоставляет источник. Работы, в которых система транспортных коммуникаций рассматривается как ключевой или один из важнейших инструментов освоения территории и управления ею, пока что не столь многочисленны ${ }^{4}$.

Вопрос о том, каким образом состояние дорог Северо-Западной Руси контролировалось и обеспечивалось новгородским правительством до 1478 г., нельзя считать выясненным. Возможно, что специальных регулярных мер с его стороны не принималось. Система сельского расселения Новгородской земли XIV-XV вв. представляла собой сеть равномерно рассредоточенных по всей территории (за исключением «неудобий») малодворных селений (в основном 1-3 двора), каждое из которых было соединено с соседними сухопутной дорогой. Такая структура расселения равномерно распределяла транспортную нагрузку на ландшафт, так что состояние дорог в этот период в целом было сносным и без специальных правительственных мер. Во всяком случае во время серии походов великого князя Ивана III на Новгород в 1470-е годы для пересечения пространства, разделявшего Новгород и

3. М.П. Погодин, «Пути сообщения в древней России» в Русский исторический сборник, издаваемый Общзеством истории и древностей Российских, т. 1, кн. 1, М: В университетской типографии, 1837, с. 1-50; И.П. Хрущов, Очерк ямских и почтовых учреждений от древних времен до изарствования Екатерины II, СПб.: Суворин, 1884; Н. Барсов, Очерки русской исторической географии: География начальной летописи, Варшава: Типография Варшавского учебного округа, 1873; 2-е изд., Варшава: Тип. К. Ковалевского, 1885; И.Я. Гурлянд, Ямская гоньба в Московском государстве до конца ХVII века, Ярославль: Тип. губ. правл., 1900; И.Я. Гурлянд, Новгородские ямские книги 1586-1631 г2. Ярославль: Тип. губ. правл., 1900; С.М. Житков, А.С. Николаев, Краткий исторический очерк развития водяных и сухопутных сообщений и торговых портов в России, СПб.: Тип. М-ва путей сообщения (Т-ва И.Н. Кушнерев и Кํ), 1900; Н.Н. Воронин, «Средства и пути сообщения» в История культуры Древней Руси. Домонгольский период, т. 1, М.; Л.: Изд-во Академии наук СССР, 1948; И.А. Голубцов, «Пути сообщения в бывших землях Новгорода Великого в XVI-XVII веках и отражение их на русской карте середины XVII века» в Bonросы географии, т. 20, М.: Географгиз, 1950, с. 271-302; А.Н. Насонов, «Русская земля» и образование территории Древнерусского государства: Историко-географическое исследование, М.: Изд-во. Академии наук СССР, 1951, с. 119; А.А. Селин, Ивангородская дорога, СПб.: Изд-во Санкт-Петербургского университета, 1996 и др.

4. Н.А. Макаров, Колонизация северных окраин Древней Руси в XI-XIII вв.: По материалам археологических памятников на волоках Белозерья и Поонежья, М.: Скрипторий, 1997; С.К. Костовска, В.О. Стулышапку, «“Книга Большому Чертежу” как историко-географический источник», Проблемы региональной экологии, 2014, №5, с. 106-110; А.А. Селин, Новгородское общество в эпоху Смуты, СПб.: Русско-Балтийский информационный центр «Блиц», 2008; М. Дадыкина, «Управляя пространством: организация Спасо-Прилуцким монастырем водных коммуникаций и их структура (XVI-XVII вв.)», Quaestio Rossica, т. 4, 2016, No 3, c. 123-140, DOI 10.15826/qr.2016.3.179. 
земли Северо-Восточной Руси, каждый раз он выбирал новый маршрут. Поэтому есть основания допускать, что предметом специального внимания правительства пути сообщения в этом регионе становятся только в Московский период - в рамках мероприятий по реформированию государственного управления и интеграции Новгородской земли в состав Московского государства. Более обстоятельному рассмотрению этого вопроса следует посвятить специальное исследование.

Известные меры по организации ямских станций на пути из Москвы в Новгород датируются в основном началом XVI в., когда ямы обеспечиваются землей5. К 1517 г. эти меры в целом дали результат, в описании маршрута Сигизмунда Герберштейна в Москву перед нами предстает уже функционирующая система. ${ }^{6}$ Процесс обустройства, который продолжался еще на рубеже 1530-1540-х гг, затронул и другие дороги Новгородской земли ${ }^{7}$.

Целенаправленные усилия свидетельствуют о том, что система дорог рассматривалась правительством как важный элемент управления. По-видимому, именно дороги стали той структурой, которая послужила основой для превращения пространства в административную территорию и для формирования видения этой территории. Уже при организации писцовых кампаний в новгородских пятинах в конце 1530-х гг, а затем при разделении работы между комиссиями, составившими книги 1550-1551 г., принималось во внимание прохождение по территории крупных дорог ${ }^{8}$. Такое членение огромной Новгородской земли позволяло при ориентации в пространстве обходиться без географической карты, опираясь только на вербальное описание. Более того, сам этот способ, по-видимому, позднее оказал сильное влияние на характер первых русских карт ${ }^{9}$.

5. По данным платежной книги Деревской пятины 1543 г., при устройстве Крестецкого яма земля была взята у Степана Лобанова Колычева. Он получил компенсацию в виде эквивалентного владения в Крестецком погосте, которое прежде было за Митей Коробьиным, а еще ранее - за Семеном Ланошинским. Последний является старым владельцем по дворцовой книге письма 1495/96-1496/97 гг. (Писцовые книги Новгородской земли, т. 1, с. 72), значит, из дворцового хозяйства в поместье М. Коробьина она попала не ранее 1495/96 г., а утрата им поместья должна была произойти по истечении еще нескольких лет с этого момента, то есть едва ли ранее начала XVI в.

6. С. Герберштейн, Записки о Московии, т. I, М.: Памятники исторической мысли, 2008, c. 621, 623; С. Герберштейн, Записки о Московии, т. II, М.: Памятники исторической мысли, 2008. Приложения. Карты. Впрочем, большинство пунктов нанес на карту еще Е.Е. Замысловский (Е.Е. Замысловский, Герберитейн и его историко-географические известия о России, СПб.: тип. бр. Пантелеевых, 1884. Приложение. Карта №6).

7. Например, незадолго до августа 1540 г. у Спасского Хутынского монастыря писцом Жихорем Рябчиковым была отписана земля для передачи под Курский ям на р. Ловати (Писиовые книги Новгородской земли, т. 4, с. 351).

8. А.А. Фролов, «“Географический фактор” в организации государственных поземельных описаний конца XV - середины XVI в.» в Книга картины Земли: Сборник статей в честь Ирины Геннадиевны Коноваловой, М.: Издательство «Индрик», 2014, c. 257-284.

9. Т.Н. Джаксон, И.Г. Коновалова, А.В. Подосинов, А.А. Фролов, Северная Евразия в картографии античности и средних веков, М.: Аквилон, 2017, с. 442-467. 
Официальная документация Русского государства, которая содержит вербальное описание географических объектов по отдельным дорожным маршрутам, хорошо известна. Ее древнейшие образцы принято относить к началу XVII в. - это, например, поверстная книга Ямского приказа (ок. 1606 г.) $)^{10}$, Роспись дорог (1601-1609 гг.) ${ }^{11}$. Подобное им описание послужило, вероятно, источником и для «Чертежа Полю», поскольку Книга Большому чертежу упоминает некую «разрядную старую роспись, что зделана роспись в Розряде при прежних государех», «против» которой «Чертеж Полю» и был изготовлен ${ }^{12}$.

Но при ближайшем рассмотрении древнейшим источником в этом ряду является новгородская Роспись погостов, которая уже двести лет известна науке, однако до недавнего времени не была атрибутирована верно. Документ, известный в современной научной литературе под названием «Выпись из новгородских изгонных книг», обнаружил Евгений Болховитинов. Он напечатал одну из ее частей - «Роспись погостов» (далее - РП $)^{13}$. Позднее текст этой публикации перепечатал Константин Алексеевич Неволин в приложении к своему исследованию о новгородских пятинах и погостах. ${ }^{14}$ Остальной текст документа под названием «Роспись дорог» (далее - РД) спустя полтора столетия опубликовал Иван Александрович Голубцов ${ }^{15}$, указав место и шифр хранения $^{16}$. Обзор истории изучения «Выписи из новгородских изгонных книг» в целом и «Росписи погостов» как ее составной части помещен в отдельном исследовании ${ }^{17}$, которое посвящено изучению структуры источника и его датировке. По результатам проделанной работы в целом источник можно охарактеризовать следующим образом.

Обнаруженное И.А. Голубцовым архивное дело относится к 1703 году. Как справедливо полагал исследователь, его возникновение связано с мероприятиями по упорядочению дорог, вызванными постройкой Петербурга.

10. А.С. Лаппо-Данилевский, Поверстная и указная книги Ямского приказа, СПб.: Тип. В.С. Балашева, 1890 , с. 1-16

11. Голубцов, «Пути сообщения в бывших землях Новгорода Великого...», с. 271-302.

12. Книга Большому чертежу / Ред. К.Н. Сербина. М.; Л.: Издательство Академии Наук CCCP, 1950, c. 49.

13. Е. Болховитинов, Исторические разговоры о древностях Великого Новгорода, М.: Губернская Типография Решетникова А.Г., 1808.

14. К.А. Неволин «О пятинах и погостах новгородских в XVI веке», Записки Русского Географического общества, 1853, т. 8, с. 383-391.

15. Голубцов, «Пути сообщения в бывших землях Новгорода Великого...», с. 271-302.

16. РГАДА (Российский государственный архив древних актов), ф. 162, Почтовые дела. 1703 г., № 5. В публикации И.А. Голубцова ошибочно указано «фонд № 128».

17. А.А. Фролов, «К вопросу об источниках "Выписи из новгородских изгонных книг” и их датировке», в Сословия, институты и государственная власть в России: Средние века и раннее Новое время. Сб. статей памяти академика Л.В. Черепнина, М.: Языки славянских культур, 2010, с. 185-198. 
РД в окончательной редакции сложилась в период с 1601 по 1609 г. ${ }^{18}$ От датировки теми же годами РП, которую предложил он, приходится отказаться, так как она основана лишь на мнении о внутреннем единстве «Выписи» и противоречит позитивным данным. «Выпись» следует охарактеризовать как опыт обобщения сведений о дорогах, содержавшихся в некоторых (возможно, случайно оказавшихся под рукой) документах Новгородской приказной палаты в начале XVIII в. РП отражает историко-географические реалии эпохи не позднее середины $1560-$ х гг. ${ }^{19}$, а результаты сравнения РП со структурой писцовых книг XV-XVII вв. однозначно свидетельствуют, что ее составитель в качестве основного источника для перечня погостов использовал комплекс книг 1540-х годов. Для Деревской пятины есть данные о времени, когда этот комплекс стал доступен новгородской администрации в окончательной редакции, - это конец 1543 г. ${ }^{20}$ Косвенным основанием сузить датировку является то, что следующая генерация писцовых книг, которой составитель РП не воспользовался, датируется 1550-1551 г. Таким образом, датировка РП находится в диапазоне между началом 1540-х гг. и серединой 1560-х гг, но наиболее вероятно, что она была составлена в период с 1544 по 1551 г.

Однако так же уверенно можно теперь утверждать, что РП имела как минимум еще один источник сведений, поскольку ни названий ямов, ни расстояний от погостов до Новгорода писцовые книги не содержат. Определенно датировать второй источник РП не представляется возможным. Однако некоторые наблюдения над составом названных в ней ямов Большой Московской дороги и других объектов, не являющихся центрами погостов, позволяют заключить, что он тоже мог быть составлен уже в первой половине XVI в. ${ }^{21}$

18. По присутствию сведений о ямах по дорогам, «отставленным» в 1596/1597 г.; упоминанию ямов, устроенных в 1599/1600 г. и названных впервые в устройных книгах 1600/1601 г.; описанию дорог на землях, утраченных Россией в 1609 г. (Голубцов, «Пути сообщения в бывших землях Новгорода Великого...», с. 278).

19. Ясеновичский и Березовецкий погосты и волость Стерж перестали быть новгородскими и были переданы ко Ржеве Володимерове не позднее 1566/1567-1567/1568 гг. (Писиовая приправочная книга 1588-1589 годов уезда Ржевы Володимеровой (половина князя Дмитрия Ивановича)/ Подгот. А.А. Фролов. М. - СПб.: Альянс- Архео, 2014, c. 368-377). Строго говоря, волость Стерж вместе с волостями Буйцы, Лопастицы, Морева, Велила и Холмским погостом (все они упомянуты в разделе РП по Деревской пятине) выходят из состава Деревской пятины уже в начале XVI в. Но на протяжении всего XVI в. эти земли, известные как Холмский уезд Новгородской земли, изредка фигурировали в делопроизводственной документации Деревской пятины, а иногда могли быть даже случайно отнесены к ней (А.А. Фролов, «Статус земель южного пограничья Новгородской земли в XVI - начале XVIII века», в Очерки феодальной России, М. - СПб.: Альянс-Архео, 2005, вып. 9, с. 114). Поэтому решающего значения факт выделения южных земель в Холмский уезд для датировки РП не имеет.

20. М.М. Бенцианов, А.А. Фролов «Платежная книга Деревской пятины 1543 г. К вопросу о функционировании системы сбора “государевых" податей в Новгородской земле в XVI столетии», Древняя Русь. Вопросы медиевистики, 2018, №1(71), с. 19-35.

21. Все ямы (за исключением Едровского) упомянуты уже в платежной книге Деревской пятины 1543 года (ПКНЗ. Т. 4. с. 371, 405 (ям Валдай), 350, 351, 462 (ям Хотилов), 427 (ям Яжолбицы), 456 (ям Крестцы), 460 (ям Бронница)). Едровский ям известен по «ободной» грамоте, которая свидетельствует о его существовании еще в 1511 году 
Представление о географии территории настолько тесно ассоциируется у современного человека с географической картой, что естественным кажется сравнить историко-географические данные того или иного источника с доступной для нас картой и судить о его точности по характеру обнаруженных расхождений. Однако для человека середины XVI в. такого эталона не существовало, так что вербальное описание фактически и формировало его представление о территории. Поэтому РП можно рассматривать как определенное отражение этого представления. Особенно ценно то, что это отражение имеет количественные характеристики, которые по сути выполняют ту же функцию, что выполняет математическая подоснова на современной карте. Задача заключается в том, чтобы научиться читать ее и интерпретировать.

Особый интерес представляет механизм исчисления приведенных в РП расстояний от Новгорода до погостов. Еще К.А. Неволин отметил, что «расстояния селений, за исключением ближайших к Новгороду, показаны круглыми числами не менее полудесятков» ${ }^{22}$. Кратность цифр десяти действительно бросается в глаза: в 346 из 378 случаев, для которых указано расстояние $(91,5 \%)$. Еще в 26 случаях цифры кратны пяти (6,9\%). Только в шести случаях $(1,6 \%)$ расстояния не кратны этим числам, причем все они относятся к ближайшей округе Новгорода $(7,23,2,3,3,4$ версты). Иными словами, расстояния от Новгорода до погостов систематически округлены до 10 верст (как частный случай - до пяти).

И.А. Голубцов обратил внимание, что «цифры расстояний при погостах во многих случаях значительно расходятся с цифрами, показанными в первой части «выписи», в росписи дорог, притом иногда в сторону большого преувеличения против дорожных цифр... реальнее и ближе к дорожным цифрам расстояния до пунктов, лежащих недалеко от Новгорода», из чего сделал вывод о том, что информация о расстояниях РП не восходит к РД и имеет самостоятельный источник, «должна была быть выбрана непосредственно из самих изгонных ямских книг, а скорее из сказок ямщиков, возивших писцов, и, может быть, из сказок самих писцов» ${ }^{23}$.

Поскольку, как мы выяснили выше, РП на три четверти столетия древнее РД, ее данные, действительно, никак не могут восходить к РД. Едва ли можно сказать наверняка, какие версты использовались в РП для измерения. Это может быть путевая верста, равная 500 трехаршинным саженям (по 216 см),

(К.В. Баранов, «Новгородская “ободная” грамота 1511/1512 года» в Русский дипломатарий, М.: Археогр. центр, 1997, вып. 5, с. 10-12). Так называемый «стан Щедковской», помещенный в РП после Борковского погоста, локализуется возле д. Щербово и соотносится с Щербовским мытом, известным по грамоте 1546 г. (Акты служилых землевладельцев XV - начала XVII века, М.: Древлехранилище, 2008, т. IV, №167). Никольский монастырь на Боровне в Ситенском погосте был основан в период между описаниями 1495-1496 гг. и конца 1530-х годов (А.А. Фролов, «О местоположении средневекового Ситенского погоста Деревской пятины» в Новгород и Новгородская земля. История $u$ археология, Великий Новгород, 2001, вып. 15, с. 268-271).

22. Неволин, «О пятинах и погостах новгородских в XVI веке», с. 35.

23. Голубцов, «Пути сообщения в бывших землях Новгорода Великого...», с. 276. 
1080 м, либо несколько меньшей длины, равная 700 малых саженей (по 152 см), ок. 1065 м. Разница в измерениях невелика, мы будем исходить из первой величины ${ }^{24}$.

Исходя из этого соотношения, мы обнаружим, что на 376 пунктов Новгородской земли, расстояние до которых из Новгорода определимо 25 , в 130 случаях (34,5\%) указанное в РП расстояние не более чем на 21 версту отличается от расстояния до Новгорода по карте, т.е. фактически равно или очень близко расстоянию по прямой. Только 19 из них относятся к ближайшей округе города (15-48 км по прямой). Остальные удалены на 51-287 км. Более того, в 100 случаях (удалены от Новгорода на 4-423 км) указанное в РП расстояние меньше, чем расстояние по прямой - эта разница составляет от 1 до 67 верст, причем в 38 из этих случаев она превышает 10 верст, поэтому не может быть объяснена простой погрешностью натурных измерений.

Ясно, что для первой половины XVI в. промер многокилометрового расстояния по прямой был задачей невыполнимой. Расстояние могло оцениваться только по длине пути (а в РП, характеризующей пути сообщения Новгородской земли, это было и главной задачей таких подсчетов), который по мере удаленности от Новгорода все более превышал расстояние по прямой. Поэтому одноразовое округление расстояния до десятков верст в меньшую сторону тоже не может объяснить такой близости цифр РП к промерам по прямой и даже их значительного уменьшения. Есть и другое обстоятельство, отмеченное еще К.А. Неволиным, которое нуждается в объяснении: иногда расположенные неподалеку погосты снабжены весьма разнящимися цифрами расстояний ${ }^{26}$.

Объяснить эти парадоксы возможно только допустив, что алгоритм подсчета расстояния в данном случае основан не на геометрии пространства, а на совершенно иных реалиях: расстояние от Новгорода до погоста исчислялось как сумма промежуточных отрезков, длина каждого из которых могла быть округлена как в меньшую, так и в большую сторону. На природу этих реалий указывает, на мой взгляд, отмеченное выше характерное округление расстояний до 10 верст. Именно с 10 верст дороги уже в середине XVI в. рассчитывался «прогон», т.е. плата за использование подводы (3 денги на 10 верст - документ 1548 г. $)^{27}$. Мысль об использовании РП в Новгородской приказной избе в качестве справочника для расчета стоимости проезда в любую точку подведомственной территории напрашивается сама собой.

24. Вслед за другими исследователями: П.Г. Бутков «Объяснение русских старинных мер, линейной и путевой», Журнал Министерства внутренних дел, 1844, ч. 8. с. 261-293; Неволин, «О пятинах и погостах новгородских в XVI веке», с. 35.

25. Не удалось локализовать лишь Филину слободку в Бежецкой пятине (№66: Неволин, «О пятинах и погостах новгородских в XVI веке», с. 386).

26. Неволин, «О пятинах и погостах новгородских в XVI веке», с. ${ }^{35-36 .}$

27. Акты служильх землевладельцев..., №100. 
Если высказанная гипотеза верна, отраженные в РП расстояния могут послужить путеводной нитью для реконструкции сети дорог, использовавшихся для ямской гоньбы. Дело в том, что при использовании алгоритма, о котором сказано выше (назовем его алгоритмом аккумуляции), удаленность погоста от Новгорода определяется в первую очередь тем, длины каких отрезков для этого суммируются. Ясно, что погост, для которого в РП указано меньшее расстояние, не мог быть достигнут через тот погост, для которого это расстояние больше. Направление, в котором к погосту подходила дорога из Новгорода, определяется по тому, какой из погостов охарактеризован в РП меньшей удаленностью от Новгорода. Погосты, охарактеризованные одинаковой удаленностью, не могут соединяться дорогой последовательно, т.е. «по цепочке». Они могут быть включены в систему дорог только «параллельно».

Особо следует учитывать существование внутри пятин уездных центров, имевших свою администрацию. Это также влияло на алгоритм расчета. Например, для всех волостей Холмского уезда, как и до города Холма, расстояние указано одно: «до всех волостей 150». В самое жесткое противоречие эта цифра вступает с пространственной удаленностью центров волостей Лопастицы и Буйцы (в РП до них указано на 13 и 31 версту меньше, чем расстояние до них от Новгорода по прямой). Ясно, что здесь вообще не использовался никакой алгоритм: оплату «прогонов» по всей территории Холмского уезда должен был обеспечить городовой приказчик г. Холма. Новгородским подьячим было достаточно снабдить должностное лицо, направленное по надобностям великого князя в Буйцы, прогонными деньгами только до Холма. Для Березовского погоста (центра волости Березовец, статус которой в первой половине XVI в. был двойственным ${ }^{28}$ ), специальный расчет был все-таки произведен: надо полагать, что до него чаще гоняли через Деманский или Полоновский погосты, минуя земли Холмского уезда.

Работа с данными об удаленности погостов осложняется тем, что применение подобной группировки в ряде случаев очевидно, но она применена лишь к некоторым погостам уезда. Это лишает возможности с легкостью отличать группировку по административному признаку от простого совпадения значений при расчете расстояний с помощью алгоритма аккумуляции. В водской части РП расстояние до половины погостов Копорского уезда равно 150 верстам - при их значительной удаленности друг от друга, хотя для другой половины погостов, физически менее удаленной от Новгорода, указанные расстояния меньше указанного значения. Особенно показательна оценка расстояния до Егорьевского Радчинского погоста. Часть его земель писцовые книги относят к Ямскому уезду, а часть - к Копорскому. Соответственно, и в РП он назван дважды, причем при упоминании в числе ямских погостов указано расстояние 160 верст, а в числе копорских - 150. Среди копорских погостов, расстояние до которых оценено в 150 верст, по своему

28. А.А. Фролов, «Статус земель южного пограничья Новгородской земли в XVI - начале XVIII века», с. 118-119. 
пространственному положению относительно погостов с меньшей удаленностью этому значению наиболее соответствует не сам г. Копорье, а Врудский погост, расположенный на Ивангородской дороге. Надо полагать, что новгородской администрацией он воспринимался как некий пункт, при достижении которого дальнейшие расчеты оплаты прогонов не требовались.

Расстоянием в 500 верст определена удаленность не только Оштинского погоста на южном берегу Онежского озера, «ворот в Заонежье», но и идущих следом вдоль берега Мегорского, Вытегорского и Андомского погостов. Но далее вновь применяется алгоритм аккумуляции, причем в случае с Шальским погостом (640 верст), судя по всему, 500-я верста считалась в Оштинском погосте, а для Пудожского погоста, через который достигались остальные погосты Заонежья, — в Андомском погосте. Оценка удаленности четырех окраинных погостов Заонежья (Петровского Челможского, Никольского в Шунге, Егорьевского в Толвуе и Спасского на Выгозере) одним числом (700 верст) при их значительном разбросе, заставляет подозревать, что и она не опирается на алгоритм аккумуляции, а дает лишь обобщенное представление о них.

В Бежецкой пятине, изученной в историко-географическом отношении в наименьшей степени (по сравнению с четырьмя другими пятинами), мы даже не вполне представляем пока, какова была группировка погостов по местным сельским центрам (городских центров здесь нет), хотя понятно, что как таковая она имела место. Очевидно, что для расположенных одним массивом, но значительно разнесенных друг от друга погостов, оцененных одним количеством верст, расстояние приводилось либо очень приблизительно, либо имела место группировка некоторой их части по административному признаку (например, удаленность соседствующих Никольского в Ливочех, Никольского в Бельске, Никольского в Климовщине, Покровского и Никольского в Черенске, Воскресенского в Избоищах, Богородицкого в Смердомле, Михайловского в Березуе и в Радуницах погостов, занимающих площадь более 1700 кв. км, определена одинаково - 250 верст). Примечателен также «шаг», с которым даны расстояния для окраин погостов Бежецкой пятины: в основном он составляет не 10-20, а 50 верст, что также указывает на чрезвычайную приблизительность подсчетов.

На южном берегу Ладожского озера отстоящие от Ярвосольского погоста на расстояние около 30 км г. Орешек и Егорьевский Лопский погост оба отличаются от него удаленностью от Новгорода, согласно РП, на 60 верст (120, 180 и 180 верст соответственно). При этом удаленность Орешка и Лопского погоста, согласно РП, равна удаленности г. Ладоги и Теребушского погоста Ладожского уезда, что дает основания подозревать здесь тоже какую-то группировку погостов по административному признаку. Но для расчета расстояния до еще более удаленных погостов, достигаемых через г. Орешек, вновь применяется алгоритм аккумуляции.

Случай с ладожскими погостами примечателен и в другом отношении: в то время как все (кроме одного) расположенные за Ладогой погосты, а также 
г. Орешек, оценены в 180 верст, для Песоцкого погоста сделано исключение до него указано 185 верст. То же самое касается округи Порхова (хотя в целом для Порховского уезда картина более сложная в связи с переплетением здесь нескольких путей, но Порхов и половина его погостов оценены в 120 верст): пригородный Карачуницкий погост удален на 125 верст. Это следует сопоставить с отмеченной выше особенностью расчета расстояний до ближайшей округи самого Новгорода - только здесь встречаются значения, не кратные 10 или 5, и отсюда же происходит большинство значений, кратных только 5. Это дает некоторые основания предполагать, что у составителя РП под рукой находились, может быть не очень комплектные, справочные материалы об удаленности погостов других уездов от их центральных городов.

Следует помнить, что документ, включающий РП, дошел до нас в виде списка начала XVIII в., и, как отметил еще И.А. Голубцов, его изготовитель не очень уверенно читал текст оригинала ${ }^{29}$. Поэтому основным критерием, который позволяет судить о точности приводимых цифр, является в целом последовательное нарастание значений по мере пространственного удаления от Новгорода. Сомнения в точности данных возникают для Ляцкого погоста Шелонской пятины (110 верст). Хотя с некоторой натяжкой граф для него удается построить, но и зависящие от него узлы также соединяются отрезками с не вполне уместными значениями длин ${ }^{30}$.

Ряд значений приходится отнести к явным ошибкам переписчика РП, если соответствующий пункт со всех сторон окружен погостами, значительно более или, наоборот, менее удаленными. В таких очень немногочисленных случаях несообразности цифр стали причиной исключения погостов из общего графа. В шелонской части РП к таким исключениям относятся Турский ${ }^{31}$ и Снежский погосты, в обонежской части РП - Михайловский погост на Черной, в бежецкой части - Дмитриевский погост в Кобоже ${ }^{32}$, Михайловский погост в Ореховне, Егорьевский погост в Чудинах и Богородицкий погост в Плавех. Соответствующие значения не коррелируют с удаленностью расположенных вокруг погостов.

Но есть и другие несообразности, которые, более вероятно, следует связывать с ошибками расчета, содержащимися уже в подлиннике РП. В этих случаях аномальные значения характеризуют несколько расположенных поблизости друг от друга погостов, а дистанция между ними вполне согласуется с реальным расположением на карте. Такие случаи следует трактовать как ошибку, допущенную однажды и повлиявшую на

29. Голубцов, «Пути сообщения в бывших землях Новгорода Великого...», с. 274.

30. Наиболее органичной с точки зрения связи с предыдущими и последующими значениями для Ляцкого погоста является удаленность в 130 верст (весьма возможным кажется ошибочное прочтение числа $\bullet$ РА• как $•$ РІ•).

31. Здесь можно предположить неверное прочтение числа $55(\cdot H \Sigma \bullet)$ как $25(\cdot \mathrm{K} \Sigma \bullet)$.

32. Альтернативное объяснение, которое пока что не чем подкрепить, — это группировка с расположенной по соседству волостью Устрека, удаленной также на 180 верст. 
оценку расстояния для более удаленных пунктов при его вычислении с помощью алгоритма аккумуляции.

Выявлены следующие случаи.

В обонежской части РП из общего ряда выбивается удаленность Никольского погоста в Шуе, оцененная в 350 верст (по прямой он находится в 410 км от Новгорода). В 55 км от него расположен Спасский погост в Кижах, удаленный от Новгорода, согласно РП, на 400 верст. Данная ошибка может быть связана с плохим знанием дороги и редкой практикой прогонов до окраин Новгородской земли. Благодаря отмеченной особенности удается установить, что Шуйский погост достигался через Олонецкий (это единственный пункт в округе, удаленность которого меньше). Вероятно, такая же неточность в подсчетах была допущена при выяснении удаленности Дмитриевского на Капщи и Никольского в Шугоозере погостов (220 верст), локализуемых недалеко друг от друга, но слишком далеко отстоящих от погостов с меньшими значениями.

Подозрения в ошибке возбуждает оценка расстояния от Новгорода до Опоцкого погоста (80 верст) и расположенных неподалеку Березского и Смолинского (70 верст) в шелонской части РП. Здесь же Черенчицкий погост показан в 170 верстах, хотя он же в деревской части РП показан в 70 верстах, что согласуется с данными о соседних погостах. В паре с Черенчицким выступает Коломенский погост, упомянутый дважды, причем в одном случае указано расстояние 80 верст, а во втором 180 верст. Здесь совершение ошибки следует видеть, во-первых, в преувеличении удаленности Черенчицкого погоста на 100 верст и, во-вторых, в определении дистанции между Черенчицким и Коломенским погостами в 10 верст (по карте расстояние составляет 27 км), что отразилось на характеристике удаленности от Новгорода дважды (80 и 180 верст)..$^{33}$

Двукратное упоминание в РП одного погоста, расположенного на границе двух пятин, является закономерностью, если ему была посвящена отдельная глава в писцовой книге соответствующей пятины начала 1540-х гг. Но не следует относить к числу ошибок все расхождения в значениях, характеризующих удаленность пункта от Новгорода, указанные в различных частях РП. Напротив, эти случаи дают дополнительное подтверждение того, что для расчета расстояний использовался алгоритм аккумуляции. Например, расположенные по левому берегу р. Волхов ладожские погосты описаны как в водской, так и в обонежской частях РП (границей между пятинами служил Волхов), и удаленность их от Новгорода оценена по-разному. Михайловский на Волхове, Ильинский на Волхове погосты и г. Ладога (с юга на север) могли быть последовательно достигнуты со стороны Новгорода по левому берегу

33. Возможно, что путаница с шелонским Коломенским погостом находится в связи с еще одной несообразностью - в водской части РП положение Коломенского погоста на Волхове показано в 90 верстах от Новгорода (по карте всего лишь 45 км). Между тем именно это значение наиболее точно характеризует положение Коломенского погоста на Ловати из шелонской части РП. 
p. Волхов, поэтому их удаленность в водской части РП оценена в 170, 175 и 180 верст. Но путь по правому берегу Волхова, ведущий в Васильевский на Волхове погост (напротив г. Ладоги) и Ильинский погост на Волхове, оценивался в обонежской части РП всего лишь в 150 верст. Их равноудаленность позволяет предположить, что переправа через Волхов на левый берег располагалась где-то между этими погостами, что находит подтверждение в названии расположенной здесь д. Извоз, известной с конца XV в. При движении этой дорогой Михайловский на Волхове погост находился на пути дальше Ильинского, поэтому в обонежской части РП его удаленность оценена в 160 верст, хотя в действительности он к Новгороду ближе.

Реконструкция сети коммуникаций, представленной в РП, была выполнена на основе приведенных выше наблюдений с помощью средства геоинформационного моделирования (программа QGIS 2.14). При этом во внимание было принято то, что РП, помимо погостов и расстояний до них, упоминает ямские станции, станы и другие пункты без указания расстояний, которые, в то же время, явно связаны с движением по тому или иному маршруту. По этой причине они включались в граф как промежуточные пункты.

Для оценки наиболее вероятного сопряжения погостов дорогами, отраженного в РП, использован коэффициент, показывающий то, как разница между удаленностью от Новгорода двух сопрягаемых погостов соотносится с реальным расстоянием между ними ${ }^{34}$. Учитывался также и ландшафт, разделяющий друг от друга два сопрягаемых пункта.

В редких случаях вероятность достижения погоста из двух пунктов оценивалась как приблизительно равная. При невозможности сделать выбор отображались оба варианта. В целом полученный граф дорог Новгородской земли середины XVI в. (рис. 1-7) является предварительной и несовершенной моделью сети дорожных коммуникаций ${ }^{35}$. Недостаточная проработанность историко-географических данных Бежецкой пятины хорошо видна по общему облику графа, покрывающего ее территорию, который отличается от облика графа в других пятинах. Вместе с тем, построенный граф может послужить толчком для детального исследования характера группировки погостов Бежецкой пятины в дальнейшем.

Полученный результат демонстрирует принципиальную адекватность данного подхода, поскольку отдельные ветви построенного графа в целом соотносятся с известными большими дорогами: Ладожской, Бельской, Дубецкой, Большой Московской, Деманской, Торопецкой, Ивангородской, Ореховской. Одним из примеров, когда построенный граф может быть сопоставлен с трассировкой по данным других источников, является Дубецкая

34. Коэффициент, равный 1 , означает точное равенство этих величин, число меньше 1 , указывает на то, что разница цифр, показывающих удаление двух погостов от Новгорода меньше, чем дистанция между ними по прямой (выраженная в верстах), число больше 1 - что разница цифр превышает дистанцию на карте.

35. Эта модель представлена также в виде веб-ГИС по адресу: https:/www.histgeo.ru/ rp.html. Со временем она может совершенствоваться. 
дорога. Судьба ее необычна. Источники XVII в. содержат лишь единичные упоминания о ней, свидетельствуя, что уже к началу столетия она утратила свою роль. Как магистраль, значимая для всего региона, Дубецкая дорога фигурирует в обыскной книге Деревской пятины Г. Плещеева и В. Чудова 1572-1573 г. - в качестве причины запустения прилегающих к ней 86 населенных пунктов, из которых 58 удалось локализовать ${ }^{36}$. Однако книга сохранилась фрагментарно, так что отдельные отрезки дороги локализовать по ней нельзя. Вместе с тем, топографические подробности маршрута движения к Новгороду в ходе «мирного похода» великого князя Ивана III в ноябре 1475 г. позволяют утверждать, что она существовала уже в XV в., и уточнить ее локализацию (рис. 2$)^{37}$.

Построенный граф, соединяющий Новгород с Ивангородом, хорошо коррелируется с Ивангородской дорогой, трассе которой посвящено специальное исследование А.А. Селина (рис. 1,4$){ }^{38}$

Принципиальное соответствие построенного графа показаниям источников о больших дорогах, на мой взгляд, дает основания охарактеризовать второй источник, использованный составителем РП, как документ, содержащий сведения о прогонах — с упоминанием названий погостов. Из того факта, что за перечнем погостов Новгородской земли составителю РП пришлось обратиться к оглавлениям современных ему писцовых книг, можно заключить, что документация о прогонах упоминала эти погосты таким образом, что из нее извлечь полный перечень погостов было гораздо сложнее. Такое было возможно, например, если в документе были записаны фактически совершенные поездки. В таком случае некоторые пункты могли упоминаться многократно в разных местах рукописи, но, с другой стороны, невозможно было быть уверенным в том, что хотя бы один раз упомянуты все сельские центры. Надо полагать, что этот источник был связан с текущим делопроизводством, обслуживающим ямскую гоньбу, вероятнее всего это был комплекс изгонных ямских книг. Они упоминаются, например, в указной

36. РГАДА, ф. 137, Устюг, №117. Лл. 131-138, 251-265, 279-792; характеристику источника см.: Г.А. Победимова, «Обыскная книга 1573 года Деревской пятины», в Вспомогательные исторические дисииплины, вып. ХІІ, Л.: Наука. Ленинградское отделение, 1981, c. 47-60. О локализации подробнее см.: А.А. Фролов, «Дубецкая дорога (к истории путей сообщения между Новгородом Великим и Северо-Восточной Русью)» в Прошлое Новгорода и Новгородской земли: Материалы научной конференции, Новгород: Новгородский государственный университет им. Ярослава Мудрого, 1998. с. 80-82.

37. В принципе верная локализация этого маршрута предложена В.Л. Яниным в работе 1982 года: В.Л. Янин, 1982. С. 151. В монографии 1981 г. исследователь опубликовал первый вариант этой локализации, менее точный (В.Л. Янин, Новгородская феодальная вотчина, М.: Наука, 1981, с. 170-171). Еще более детальная локализация предложена в статье: А.А. Фролов, «О маршруте «мирного похода» Ивана III на Новгород» в Новгород и Новгородская земля: история и археология: Материаль научной конференции, Новгород: Новгородский государственный объединенный музей-заповедник, 1997, вып. 11, с. 320-330.

38. А.А. Селин, Ивангородская дорога, СПб.: Изд-во Санкт-Петербургского университета, 1996. 
грамоте о проверке отчетности Тотемского яма: «А у прежних бы еси ямщиков у Малофейки с товарыщи и книги ямские взял да по тем бы еси книгам тех прежних ямщиков сметил, сколько они при своей стряпне подвод по которой дороге отпустили» ${ }^{39}$.

Независимо от того, как достигался из Новгорода тот или иной пункт подведомственной территории, приведенные цифры расстояний позволяют, с помощью геоинформационных технологий, визуализировать «административный рельеф» Новгородской земли середины XVI в. в виде анаморфированной карты, адекватно передающей географическое положение всех локализованных 378 пунктов, но изображающей удаленность от Новгорода по данным РП в виде высотной отметки. При создании карты самой высокой точкой стал Новгород. Чем дальше от него РП помещает тот или иной погост, тем меньшую высотную отметку он имеет на анаморфированной карте. Ниже всего располагаются погосты, удаленные на 700 верст - их отметка - 700. Интерполяция по точкам (по методу обратного степенного расстояния) позволила представить и «административный рельеф» в виде горизонталей (рис. 8) и в виде трехмерной модели (рис. 9). Последняя - это вариант реконструкции той ментальной карты, которая документирована данными РП.

Институт всеобщей истории РАН, Москва

npkfrolov@gmail.com 
Рис. 1 - Модель дорог Новгородской земли 1540-х годов по данным «Росписи погостов» (Лист 1). Погосты подписаны парами значений, из которых первое - номер в порядке упоминания пункта в РП, второе (в скобках) удаленность пункта от Новгорода в верстах, согласно РП.

Для порядковых номеров погостов, см. с. 128

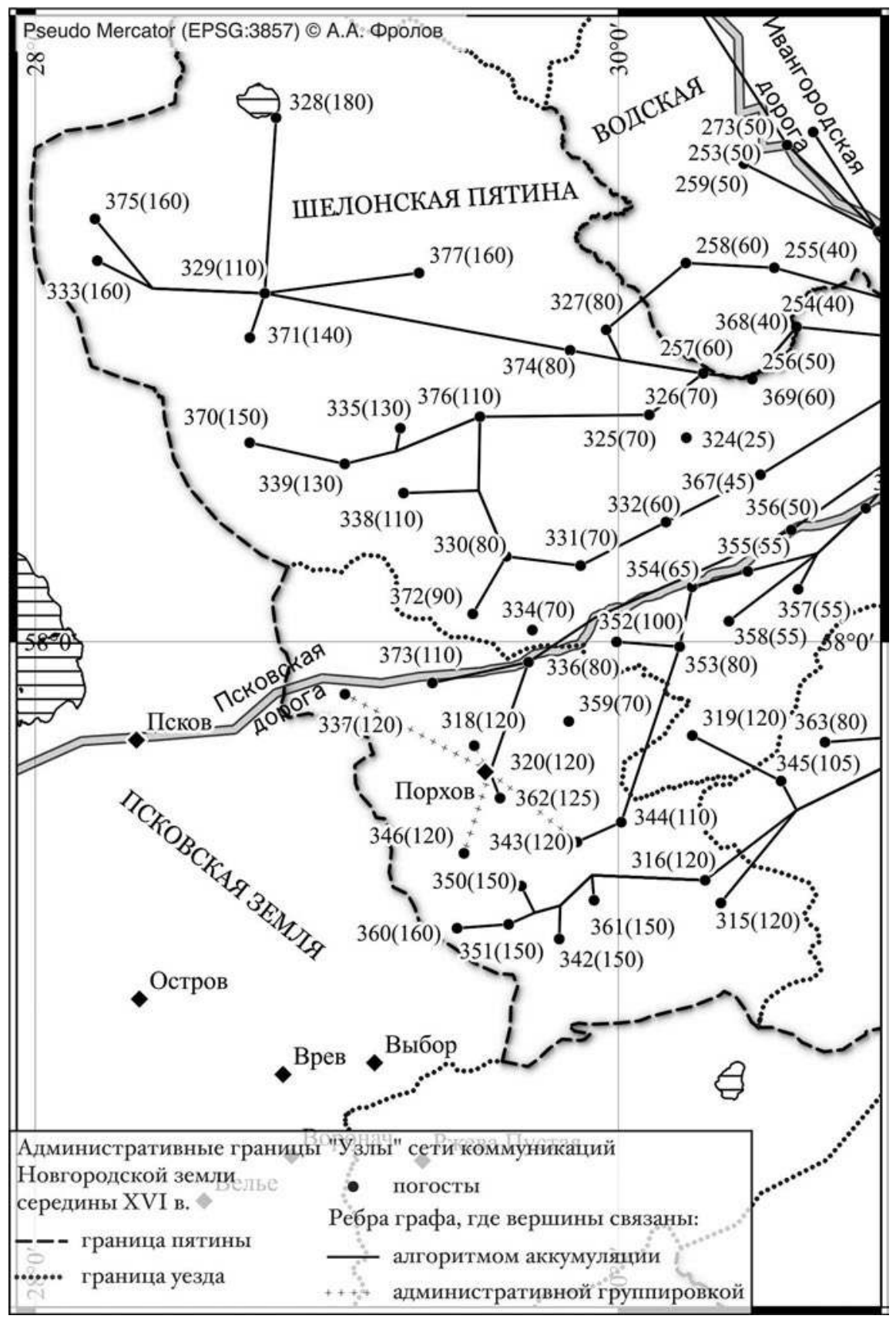


Рис. 2 - Модель дорог Новгородской земли 1540-х годов по данным «Росписи погостов» (Лист 2).

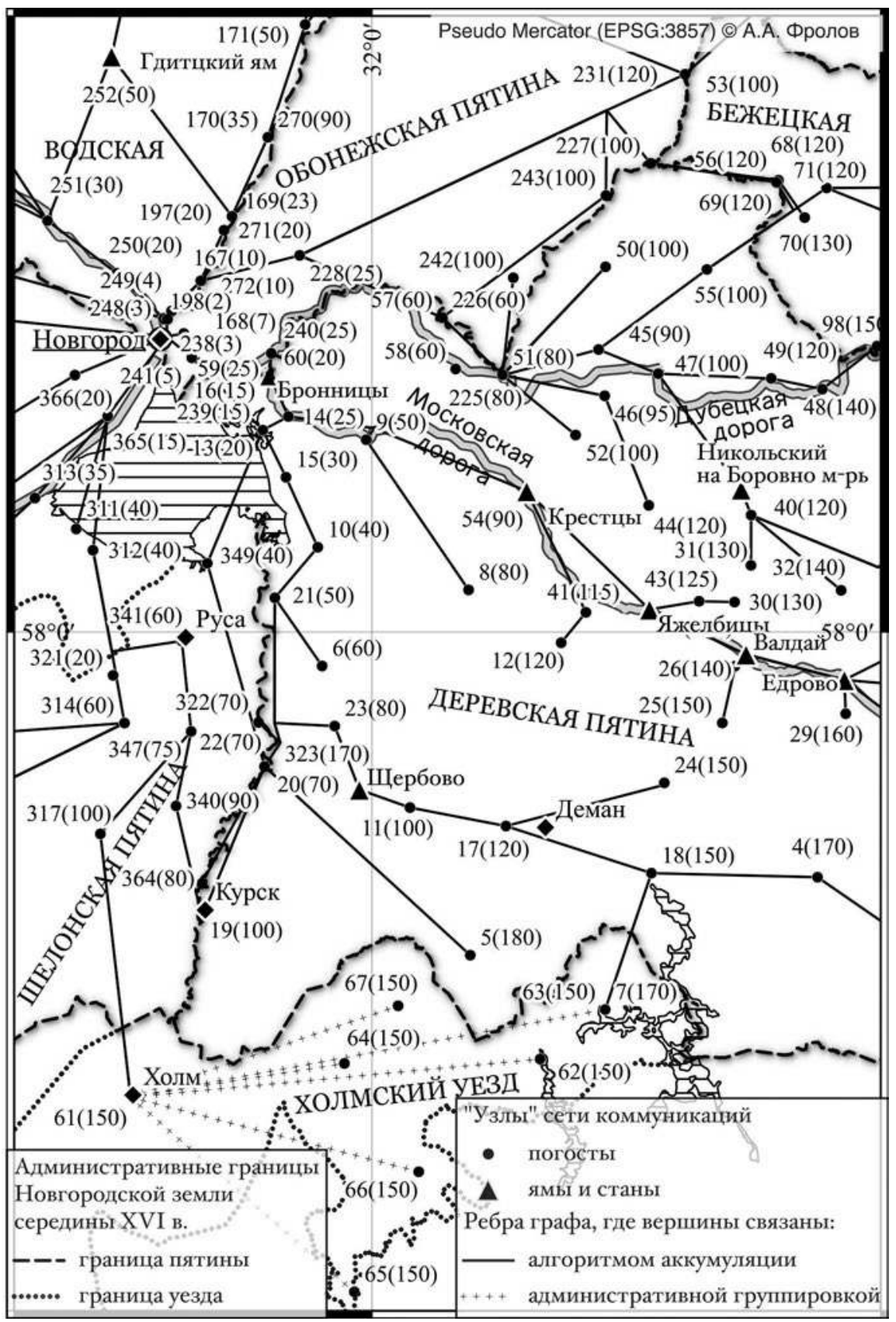


Рис. 3 - Модель дорог Новгородской земли 1540-х годов по данным «Росписи погостов» (Лист 3).

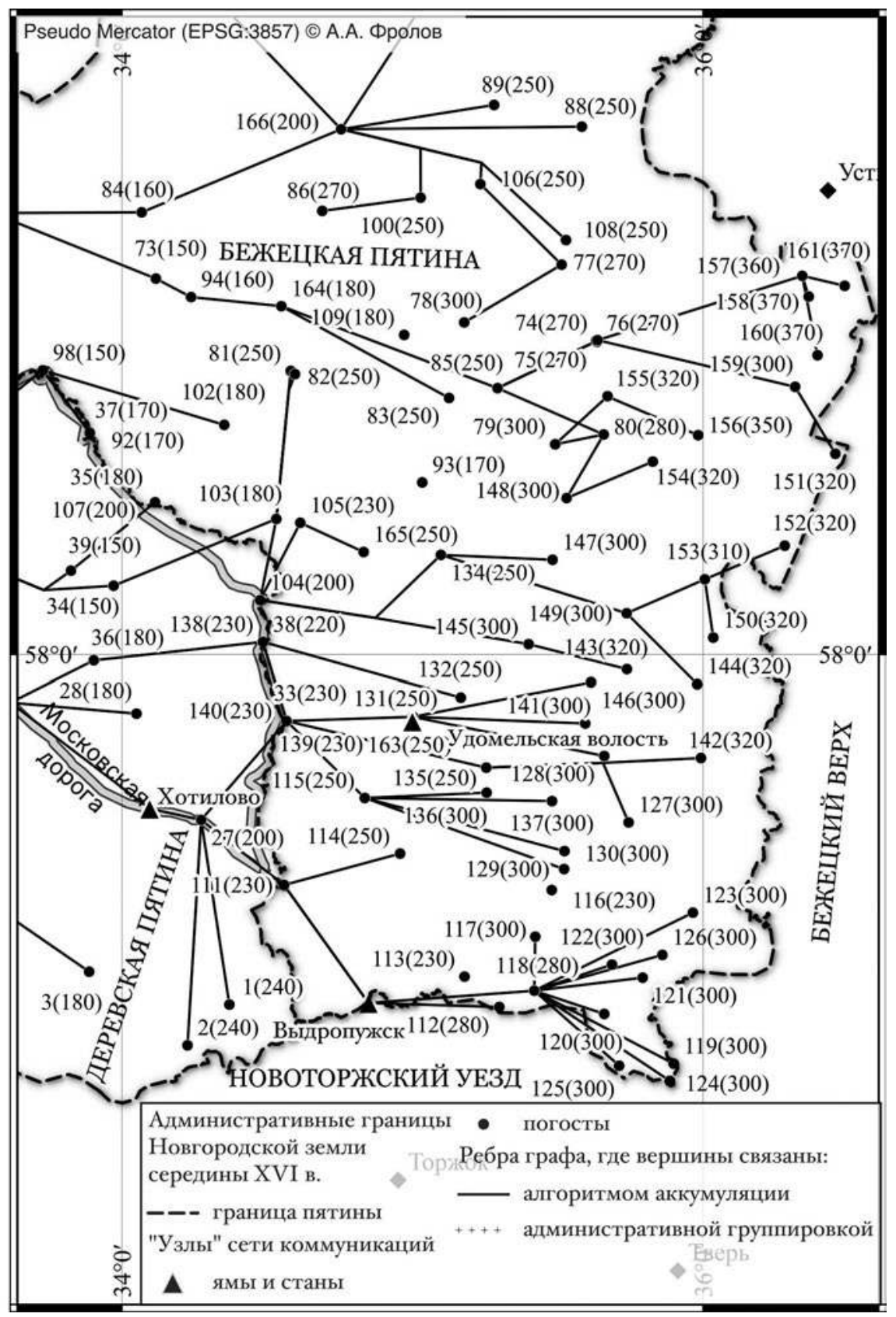


Рис. 4 - Модель дорог Новгородской земли 1540-х годов по данным «Росписи погостов» (Лист 4).

\section{Админнистративные границы Новгородской земли середины XVI в. \\ - - граница пятины \\ ....... граница уезда}

"Узлы" сети коммуникаций

4. ямы и станы

- погосты

Ребра графа, где вершины связаны:

— алгоритмом аккумуляции

++++ административной группировкой

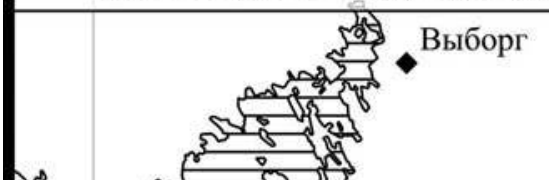

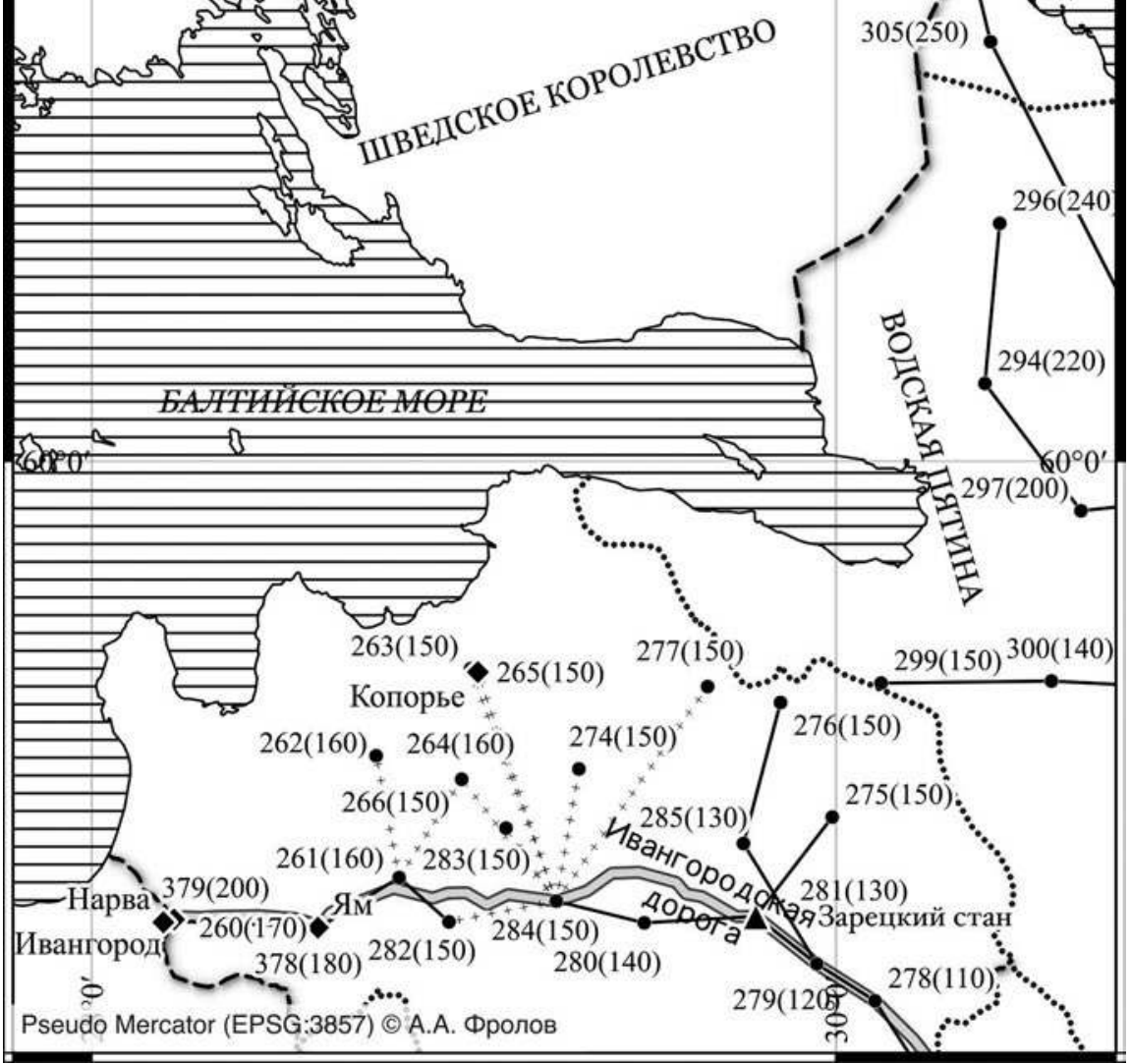


Рис. 5 - Модель дорог Новгородской земли 1540-х годов по данным «Росписи погостов» (Лист 5).

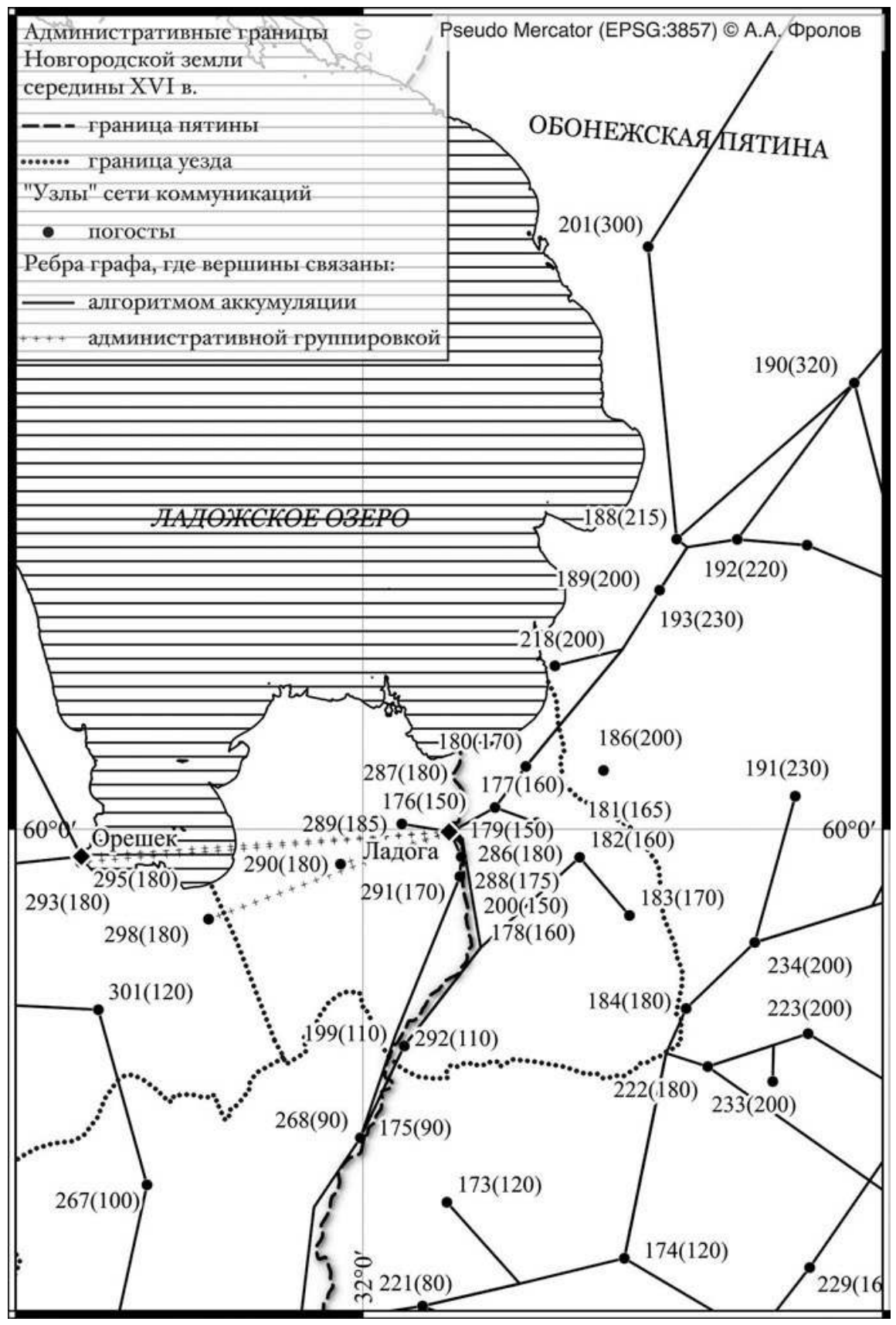


Рис. 6 - Модель дорог Новгородской земли 1540-х годов по данным «Росписи погостов» (Лист 6).

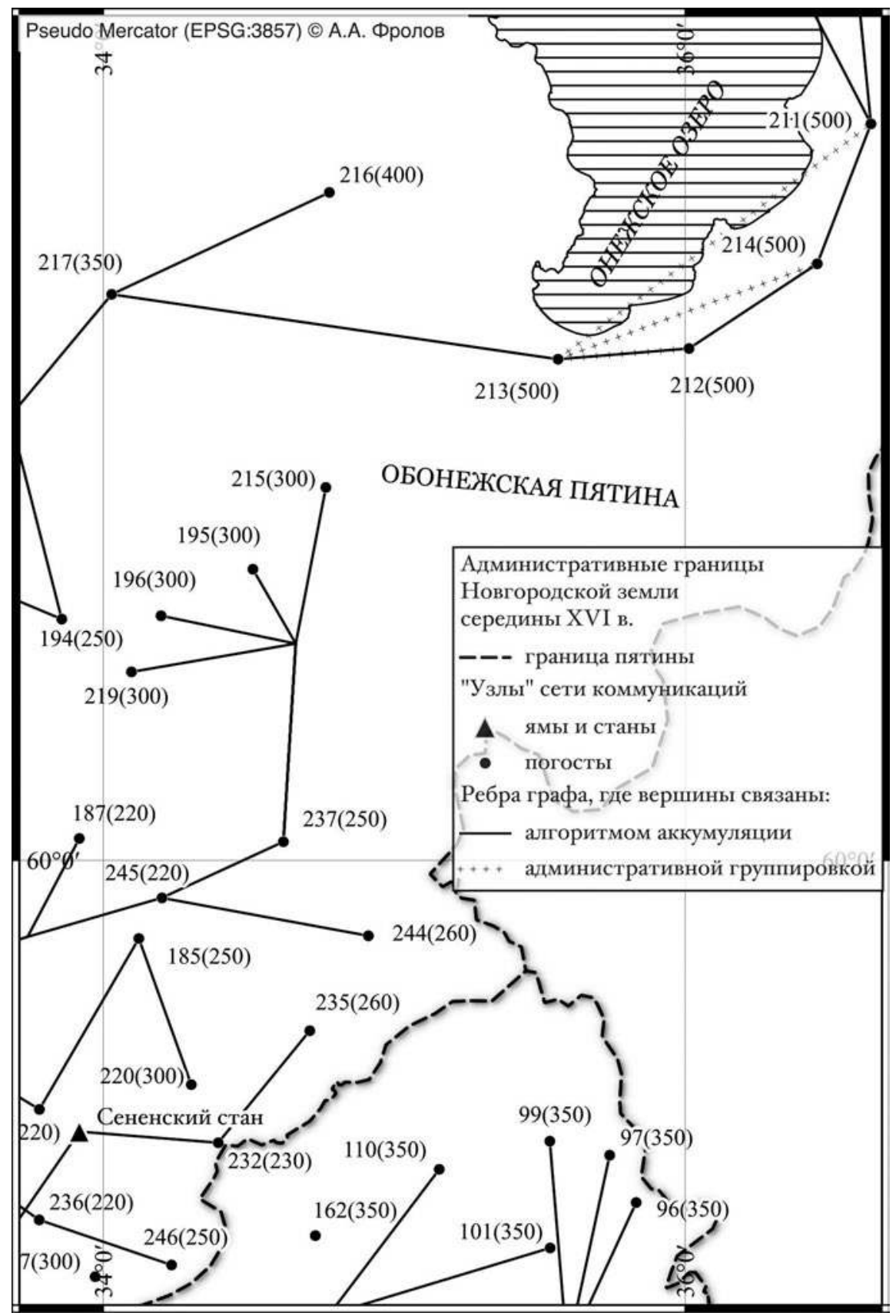


Рис. 7 - Модель дорог Новгородской земли 1540-х годов по данным «Росписи погостов» (Лист 7).

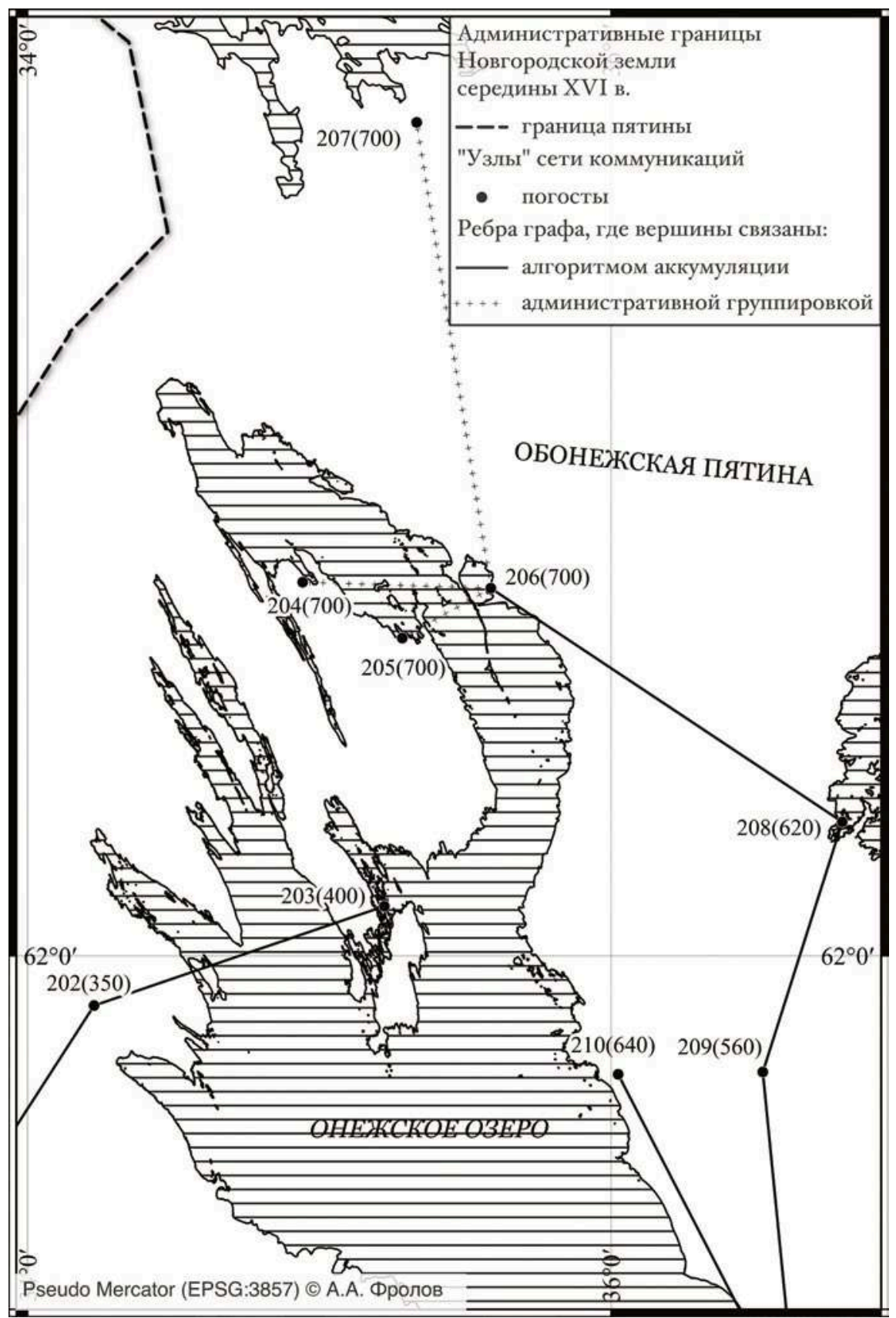


Рис. 8. «Административный рельеф» Новгородской земли 1540-х годов по данным «Росписи погостов»: анаморфированная карта.

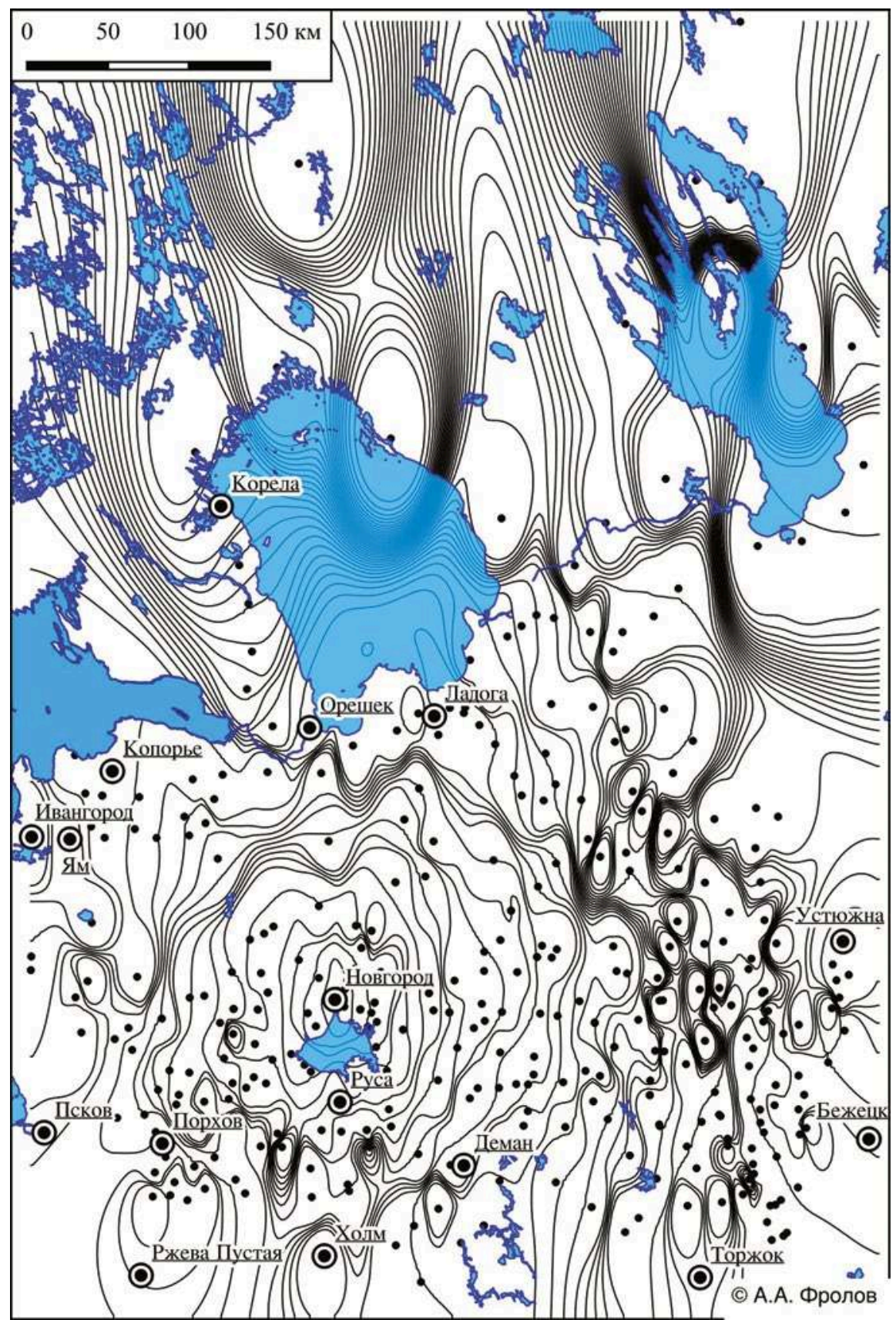


Рис. 9. Трехмерная реконструкция «административного рельефа» Новгородской земли 1540-х годов по данным «Росписи погостов».

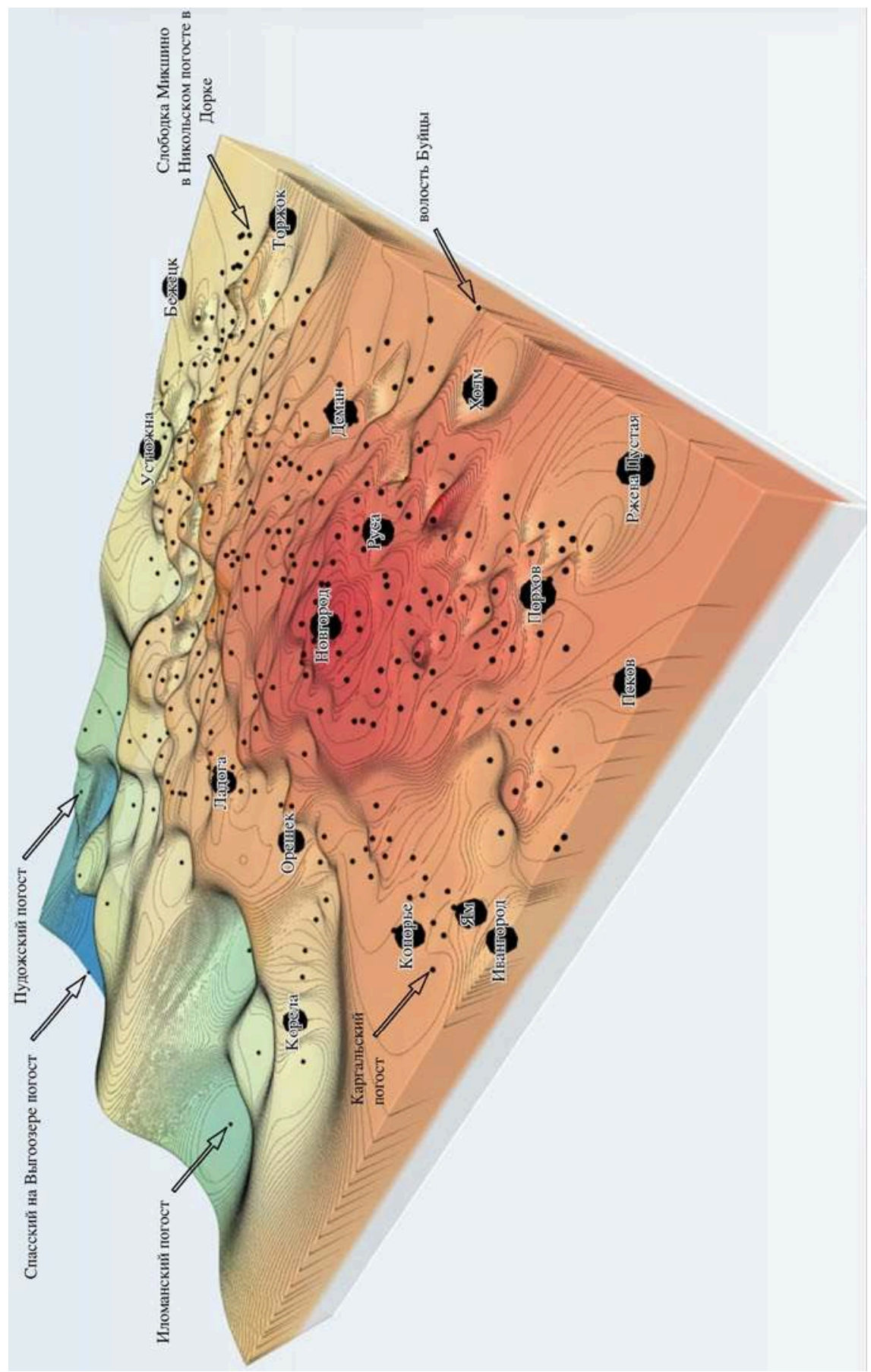




\section{Подписи к иллюстрациям:}

Рис. 1-7. Модель дорог Новгородской земли 1540-х годов по данным «Росписи погостов». Погосты подписаны парами значений, из которых первое - номер в порядке упоминания пункта в РП, второе (в скобках) - удаленность пункта от Новгорода в верстах, согласно РП. Порядковые номера погостов:

Деревская часть РП: 1 - Заборовский; 2 - Ясеновичский; 3 - Посонский; 4 - Жабенский; 5 - Молвятицкий; 6 - Борковский; 7 - Березовец; 8 - Листовичский; 9 - Тухольский; 10 - Влажинский; 11 - Буховский; 12 - Семеновский в Удрицах; 13 - Наволоцкий; 14 - Понедельский; 15 - Сытинский; 16 - Холынский; 17 - Деманский; 18 - Полоновский; 19 - Старокурское; 20 - Черенчицкий; 21 - Устьянский;22 - Рамышевский;23 - Налючский;24 - Вельевский; 25 - Городненский; 26 - Короцкий; 27 - Коломенский; 28 - Бологовский; 29 - Михайловский; 30 - Нерецкий; 31 - Ужинский; 32 - Туренский; 33 - Млевский; 34 - Рютинский; 35 - Великопорожский; 36 - Березайский; 37 - Боровичский; 38 - Сеглинский; 39 - Пиросский; 40 - Ситенский; 41 - Налеский; 42 - Яжелбицкий; 43 - Еглинский; 44 - Локотский; 45 - Островский; 46 - Черньчевичский; 47 - Теребуновский; 48 - Шегринский; 49 - Полищский; 50 - Оксоцкий; 51 - Усть-Воломский; 52 - Ручьевский; 53 - Кременичи; 54 - Крестецкий; 55 - Язвищский; 56 - Бельской Богородицкий; 57 - Морозовичский; 58 - Холовский; 59 - Боженский; 60 - Бронницкий; 61 - Холмский; 62 - Стерж; 63 - Березовец; 64 - Велила; 65 - Буец; 66 - Лопастица; 67 - Морева;

Бежеикая часть РП: 68 - Прокофьевский на Белой; 69 - Богородицкий на Белой; 70 - Ильинский в Люботинах; 71 - Никольский в Шереховичах; 72 - Никольский в Моркиничах; 73 - Богородицкий в Сопинах; 74 - Троицкий в Охоне; 75 - Никольский в Охоне; 76 - Иванский в Охоне; 77 - Егорьевский в Кирве; 78 - Васильевский в Черной; 79 - Михайловский в Михайлове Конце; 80 - Богородицкий Волдомицкий; 81 - Никольский в Мошне; 82 - Спасский в Мошне; 83 - Егорьевский в Бродех; 84 - Спасский в Молодильне; 85 - Дмитриевский Устецкий; 86 - Козмодемьянский в Кушавере; 87 - Богородицкий Смердомля; 88 - Покровский и Никольский в Черенске; 89 - Воскресенский в Избоищах; 90 - Никольский в Мегрине; 91 - Егорьевский в Озереве; 92 - Петровский и Борисоглебский в Боровичах; 93 - Михайловский в Ореховне; 94 - Никольский в Любонех; 95 - Михайловский в Березуе и в Радуницах; 96 - Никольский в Колодне; 97 - Ильинский в Веси; 98 - Никольский и Покровский на Волочке Дершкове; 99 - Никольский в Любочех; 100 - Никольский в Ливочех; 101 - Ильинский в Люботине; 102 - Егорьевский в Телбовичах; 103 - Васильевский в Болонье; 104 - Никольский на Березове Ряду; 105 - Покровский в Заозерицах; 106 - Никольский в Бельске; 107 - Никольский Великопорожский; 108 - Никольский в Климовщине; 109 - Дмитриевский в Кобоже; 110 - Иванский Вольский; 111 - Никольский на Вышнем Волочке; 112 - Егорьевский Мокрый; 113 - Егорьевский в Чудинах; 114 - Воскресенский в Осечне; 115 - Егорьевский в Осечне; 116 - Богородицкий в Плавех; 
117 - Спасский в Клинце; 118 - Богородицкий Дорский; 119 - Никольский в Дорке; 120 - Богородицкий Залазна; 121 - Воскресенский Клин; 122 - волость Забрусье; 123 - Михайловский Тростный; 124 - Слободка Стучева в Никольском погосте в Дорском; 125 -Слободка Микшино в Никольском же погосте; 126 - Иванский Заручек и Пруды; 127 - Васильевский Кострецкий; 128 - Никольский Ворожба; 129 - Богородицкий Замутье; 130 - Петровский Тихвинский; 131 - Никольский и волость Боярщина; 132 - волость Мушина; 134 - Егорьевский и Удомельский в Илове; 135 - Никольский и Покровский в Поддубье в Удомельском; 136 - Никольский в Молдине; 137 - Покровский на Волчине и волость Поляна; 138 - Богородицкий в Сеглинах; 139 - Егорьевский Млево; 140 - Спасский во Млеве; 141 - Никольский Рай; 142 - Богородицкий Рыбенский; 143 - Богородицкий Загородье; 144 - волость Сельца; 145 - Михайловский Коства; 146 - Михайловский Лощемля; 147 - Покровский Сорогошино; 148 - Никольский Смердыни; 149 - Никольский Забережье; 150 - Никольский Гостиничи; 151 - Слободка Тараскова в Покровском погосте; 152 - слободка Мирогожская Дуброва в Покровском погосте; 153 - Никольский Добрыни; 154 - слободка на Мологе на великом пороге в Богородицком погосте в Павскем; 155 - Богородицкий Волдомицкий в Вятке; 156 - Богородицкий в Павске в Слезкине; 157 - Спасский в Слезкине; 158 - Ильинский в Слезкине; 159 - Никольский в Слезкине 1; 160 - Никольский в Слезкине 2; 161 - Воскресенский в Слезкине; 162 - волость Суглица; 163 - волость Удомля; 164 - волость Устрека; 165 - волость Липна; 166 - Егорьевский на Минце;

Обонежская часть РП: 167 -Иванский на Волхове; 168 -Хутынский Введенский; 169 - Антониевский на Волхове; 170 - Коломенский на Волхове; 171 - Полистский на Волхове; 172 - Андреевский Грузинский; 173 - Никольский на Пшеуже; 174 - Петровский на Пшеуже; 175 - Солецкий на Волхове; 176 - Климецкий на Волхове; 177 - Троицкий на Златыни; 178 - Михайловский на Волхове; 179 - Васильевский на Волхове; 180 - Богоявленский на Сяси; 181 - Рождественский на Сяси; 182 - Никольский на Сяси; 183 - Воскресенский на Сяси; 184 - Ильинский на Сяси; 185 - Никольский Явозма; 186 - Воскресенский на Масельге; 187 - Дмитриевский на Капщи; 188 - Введенский на Ояти Сермакса; 189 - Рождественский на Пашском устье; 190 - Пиркинский; 191 - Спасский на Шижне; 192 - Никольский на Ояти; 193 - Вымоченицкий на Ояти; 194 - Михайловский в Гедевичах; 195 - Никольский в Ярославичах; 196 - Дмитриевский в Сотских; 197 - Петровский на Волхове; 198 - Деревяницкий; 199 - Городицкий на Волхове; 200 - Ильинский на Волхове; 201 - Рождественский на Олонце; 202 - Никольский в Шуе; 203 - Спасский в Кижах; 204 - Никольский в Шунге; 205 - Егорьевский в Толвуе; 206 - Петровский Челможский; 207 - Спасский на Выгоозере; 208 - Водлоозерский; 209 - Пудожский; 210 - Шальский; 211 - Андомский; 212 - Мегорский; 213 - Оштинский; 214 - Вытегорский; 215 - Веницкий; 216 - Острочинский; 217 - Важинский; 218 - Воронажский; 219 - Михайловский в Тервиничах; 220 - Михайловский в Озерах; 221 - Пречистой в Деревах; 
222 - Воскресенский на Липне; 223 - Пречистенский на Тихвине; 224 - Антоньевский в Дымех; 225 - Усть-Воломский; 226 - Никольский в Морозовичах; 227 - Никольский в Моркиничах; 228 - Мытенский; 229 - Никольский в Дреглех; 230 - Егорьевский в Неболчах; 231 - Кременичский; 232 - Воскресенский в Лучанех; 233 - Петровский на Мелегижи; 234 - Егорьевский на Кожеле; 235 - Егорьевский в Кувушах; 236 - Климецкий в Колбягах; 237 - Никольский на Паше озере; 238 - Волотовский; 239 - Петровский на Холыни; 240 - Пречистенский Боженский; 241 - Петровский на Кунине; 242 - Покровский на Хубцах; 243 - Коломенский на Мсте; 244 - Никольский в Пелушах; 245 - Никольский в Шугоозере; 246 - Никольский Волок Хотславль; 247 - Михайловский на Черной;

Водская часть РП: 248 - Григорьевский Кречневский; 249 - Никольский на Пидьбе; 250 - в Заверяжье; 251 - Егорьевский Лужский; 252 - Дмитриевский Гдицкий; 253 - Спасский на Оредеже; 254 - Сабельский; 255 - Успенский Хрепельский; 256 - Косицкий; 257 - Никольский Передольский; 258 - Дмитриевский Городенский; 259 - Никольский Бутковский; 260 - Яма и Ямское окологородье; 261 - Ополецкий в Чуди; 262 - Никольский Толдожский; 263 - Каргальский; 264 - Егорьевский Ратчинский; 265 - город Копорье на реке Копорье; 266 - Егорьевский Ратчинский; 267 - Ильинский Тигодский; 268 - Солецкий на Волхове; 269 - Андреевский на Грузине; 270 - Коломенский на Волхове; 271 - Петровский на Волхове; 272 - Ивановский Переежский; 273 - Климецкий в Тесове; 274 - Никольский Замошский; 275 - Петровский Дятелинский; 276 - Дмитриевский Кипенский; 277 - Богородицкий Дягелинский; 278 - Спасский Орлинский; 279 - Никольский Грезневский; 280 - Покровский Озерецкий; 281 - Спасский Зарецкий; 282 - Никольский Ястребинский; 283 - Григоровский; 284 - Богородицкий Врудский; 285 - Егорьевский Вздылицкий; 286 - г. Ладога на реке Волхове; 287 - Успенский Городенский; 288 - Ильинский на Волхове; 289 - Федоровский Песоцкий; 290 - Егорьевский Теребужский; 291 - Михайловский на Волхове; 292 - Никольский с Городища; 293 - Спасский Городенский; 294 - Воздвиженский Корбосельский; 295 - г. Орешек на Неве; 296 - Ивановский Куйвошский; 297 - Ильинский Келтушский; 298 - Егорьевский Лопский; 299 - Введенский Дудоровский; 300 - Никольский Ижорский; 301 - Никольский Ярвосольский; 302 - г. Корела на реке Узерве; 303 - Городенский; 304 - Михайловский Сакульский; 305 - Васильевский Ровдужский; 306 - Богородицкий Кирьяжский; 307 - Никольский Сердовольский; 308 - Ильинский Иломанский; 309 - Воскресенский Соломанский;

Шелонская часть РП: 311 - Коростынский; 312 - Бурежский; 313 - Голинский; 314 - Дретонский; 315 - Дегожский; 316 - Рождественский на Усть-Северы; 317 - Лосский; 318 - Михайловский на Узе; 319 - Михайловский Юрьева монастыря; 320 - г. Порхов и окологородье Порховское; 321 - Снежский; 322 - Рамышевский; 323 - Черенчицкий; 324 - Турский; 325 - Фроловский; 326 - Передольский; 327 - Петровский; 328 - Сумерский; 329 - Ляцкий; 330 - Боротенский; 331 - Вшелский; 332 - Лубинский; 333 - Прибужский; 
334 - Березский; 335 - Хмерский; 336 - Опоцкий; 337 - Ручьевский; 338 - Логовещский; 339 - Щирский; 340 - Офремовский; 341 - Руса и Руский уезд и Околорусье; 342 - Пажеревицкий; 343 - Болчинский; 344 - Бельский Юрьева монастыря; 345 - Должинский; 346 - Ясенский; 347 - Воскресенский на Порусье; 348 - Коломенский; 349 - Чертицкий; 350 - Облуцкий; 351 - Вышегородский; 352 - Илеменский; 353 - Ретенский; 354 - Скнятинский; 355 - Свинорецкий; 356 - Струпинский; 357 - Любынский; 358 - Доворецкий; 359 - Смолинский; 360 - Жедрицкий; 361 - Никольский Высоцкий; 362 - Карачуницкий; 363 - Славятинский; 364 - Коломенский; 365 - Паозерский; 366 - Сутоцкий; 367 - Медведский; 368 - Сабельский; 369 - Косицкий; 370 - Быстреевский; 371 - Лосицкий; 372 - Павский; 373 - Дубровенский; 374 - Дремяцкий; 375 - Щепецкий; 376 - Которский; 377 - Бельский; 378 - Ямской уезд; 379 - Ивангород и Ивангородский уезд. 
